
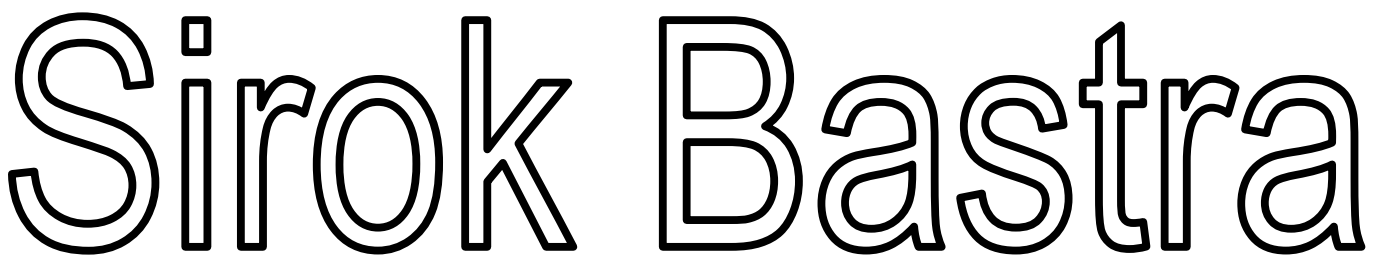

JURNAL ILMIAH KEBAHASAAN DAN KESASTRAAN

\begin{tabular}{|c|c|c|c|c|c|}
\hline $\begin{array}{c}\text { Sirok Bastra } \\
\text { Jurnal Kebahasaan dan } \\
\text { Kesastraan }\end{array}$ & Volume 2 & Nomor 2 & $\begin{array}{c}\text { Hlm. } \\
121-210\end{array}$ & $\begin{array}{l}\text { Pangkalpinang, } \\
\text { Desember 2014 }\end{array}$ & $\begin{array}{c}\text { ISSN } \\
2354-7200\end{array}$ \\
\hline
\end{tabular}

KANTOR BAHASA PROVINSI BANGKA BELITUNG 


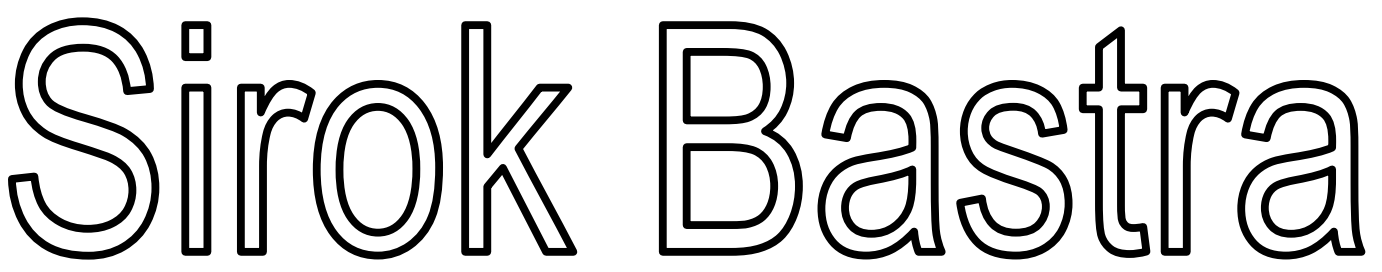

JURNAL ILMIAH KEBAHASAAN DAN KESASTRAAN

Jurnal ini merupakan wadah informasi mengenai kebahasan, kesastraan, dan pengajarannya yang memuat hasil penelitian, studi kepustakaan, dan tulisan ilmiah bidang kebahasan dan kesastraan serta pengajarannya. Sirok Bastra terbit dua kali setahun, yakni Juni dan Desember, serta terbit sejak Juni 2013.

\section{Penanggung Jawab}

Kepala Kantor Bahasa Provinsi Bangka Belitung Drs. Umar Solikhan, M.Hum.

Mitra Bestari

Prof. Dr. Agus Nuryatin, M.Hum. (Bidang Sastra dan Pengajarannya)

Prof. Amrin Saragih, Ph.D., M.A. (Bidang Bahasa dan Pengajarannya)

Dr. Felicia Nuradi Utorodewo, M.Hum. (Bidang Bahasa dan Pengajarannya)

Dr. Pujiharto, M.Hum. (Bidang Sastra dan Pengajarannya)

\section{Pemimpin Redaksi}

Rahmat Muhidin, S.S.

\section{Penyunting}

Prima Hariyanto, S.Hum.

\section{Perancang Sampul}

Feri Pristiawan, S.S.

\section{Kesekretariatan}

Khaliffitriansyah, S.Pd.

Dea Letriana Cesaria, S.Hum.

Lia Aprilina, S.Pd.

Andrian Priyatno, A.Md.

Elzam

\section{Alamat Redaksi dan Penerbit}

Kantor Bahasa Provinsi Bangka Belitung

Ruko Permata 7, Jalan Solihin G.P. Km 4, Kota Pangkalpinang, Prov. Kepulauan Bangka Belitung

Telp./Faks.: 0717-438455, Pos-el: sirokbastra@gmail.com, sirokbastra@kemdikbud.go.id

Pemuatan suatu tulisan dalam jurnal ini tidak berarti redaksi menyetujui isi tulisan tersebut. Isi tulisan menjadi tanggung jawab penulis. Tulisan telah ditinjau dan diulas oleh mitra bestari. Setiap karangan dalam jurnal ini dapat diperbanyak setelah mendapat izin tertulis dari penulis, redaksi, dan penerbit. 


\section{PENGANTAR}

Puji syukur ke hadirat Pemilik dan Pencipta semesta ini yang memiliki kuasa atas diri-Nya sendiri. Dialah Tuhan Yang Maha Esa yang telah memberikan rahmat dan hidayah-Nya sehingga Volume 2 Nomor 2 Jurnal Sirok Bastra Tahun 2014 dapat terbit tepat pada waktunya.

Pada edisi ini, dimuat sepuluh tulisan, yakni satu tulisan kebahasaan, satu tulisan pengajaran bahasa, dan delapan tulisan kesastraan. Dalam penelitiannya, Anitawati Bachtiar, Adek Dwi Oktaviantina, dan Rukmini membahas penggunaan alih kode dan campur kode pada dialog ubrug. Berdasarkan penelitian, ditemukan bentuk alih kode intern, berupa peralihan dari bahasa Jawa Serang menjadi Sunda Banten dan sebaliknya, serta alih kode metaforis dan situasional. Terdapat pula campur kode ke dalam yang berbentuk penyisipan kata pada kalimat yang diucapkan para pemain. Tujuan penggunaan alih kode dan campur kode itu adalah untuk memecah kekakuan saat pementasan, serta membangkitkan rasa humor agar penonton dapat terhibur.

Abdul Aziz melakukan penelitian yang bertujuan untuk mengupayakan peningkatan keterampilan siswa dalam menulis paragraf melalui metode inkuiri dengan menggunakan media audio pada siswa kelas $\mathrm{X}_{1}$ SMA DDI Alliritengae, Kabupaten Maros. Hasil penelitian menunjukkan bahwa metode inkuiri dengan menggunakan media audio dapat meningkatkan kemampuan menulis paragraf siswa kelas $\mathrm{X}_{1}$ SMA DDI Alliritengae, Kabupaten Maros pada tahap pelaksanaan dan tahap penilaian.

Dalam kajiannya, Tri Lia memaparkan nilai sosial dan budaya dalam cerita pendek "Sri Sumarah" karya Umar Kayam. Berdasarkan analisis, ditemukan beberapa nilai sosial budaya yang terdapat dalam cerita pendek ini, yaitu wayang dan stratifikasi sosial, masyarakat Jawa yang nrimo, sistem sapaan dalam masyarakat Jawa, mistik kejawen, masyarakat Jawa yang pembalas budi, keselarasan hidup masyarakat Jawa, dan latar politik PKI.

Dalam kajiannya, Dindin Samsudin membandingkan teka-teki (pertanyaan tradisional) yang terdapat di Provinsi Nanggroe Aceh Darussalam, yakni hiem dan yang terdapat di Provinsi Jawa Barat, yakni tatarucingan. Berdasarkan penelitian, terdapat beberapa hiem Aceh dan tatarucingan Sunda yang memiliki persamaan.

Dalam kajiannya, Kurniati membahas novel Orang-Orang Proyek karya Ahmad Tohari yang menurutnya berusaha menghadirkan sebuah realitas kemanusiaan, yakni melawan korupsi dan berbagai penyimpangan. Penulis menunjukkan bahwa di dalam novel tersebut terdapat kebenaran sosial. Karya ini memiliki sebab dan hasil kehebatan nilai artistik sebuah karya sastra (dengan dokumen sosialnya) sebagai potret kenyataan sosial.

Dalam penelitiannya, Sony Sukmawan membahas apokaliptisme sastra lisan Lereng Arjuna. Ciri-ciri yang terdapat dalam sastra lisan Lereng Arjuna dalam wujud (i) pemahlawanan tokoh mitologis dan sosok cikal bakal, trindih ukir, atau babat alas desa setempat; (ii) implikasi gagasan apokaliptik di balik latar penamaan desa, latar penamaan situs-situs purbakala, dan situs keramat alami; (iii) penamaan para-baureksa dalam mantra; serta (iv) pengungkapan apokaliptik sebagai pemulihan stabilitas alam melalui tindakan pencegahan yang persuasif.

Hestiyana membahas tema dan amanat cerita rakyat di Kecamatan Karang Intan, Kabupaten Banjar. Dalam penelitiannya, ditemukan tiga bentuk cerita rakyat, yaitu dongeng, legenda, dan mite. Cerita rakyat tersebut terdiri atas satu dongeng yang berjudul "Ular Tadung di Gunung Kiyau"; dua legenda berjudul "Asal Usul Nama Desa Karang Intan" dan "Asal Usul Nama Danau Purun"; dan satu mite berjudul "Pamandian Putri di Gunung Putra Bulu".

Dalam penelitiannya, Helmina Kastanya membahas tradisi lisan tatabuang manare dan badendang yang merupakan salah satu kekayaan sastra yang mengandung nilai estetika dalam pesta pernikahan masyarakat Pulau Ambon. Berdasarkan penelitian, bentuk tradisi lisan tatabuang manare dan badendang adalah prosesi berbalas pantun sambil menari diiringi alunan musik totobuang dan tifa. Tradisi ini berfungsi sebagai media penyatuan dua keluarga yang baru menjadi besan. Adapun nilai yang terkandung di dalamnya adalah nilai percintaan, kekeluargaan, dan sosial.

Dalam penelitiannya, Bagus Kurniawan membahas strategi pembacaan dekonstruksi karakter Arjuna sebagai lelananging jagad dalam lakon-lakon wayang purwa. Menurutnya, pemaknaan terhadap wayang masa kini mulai beragam, tidak hanya melalui dikotomi hitam-putih, tetapi juga melalui berbagai tafsir yang kemudian 
mendekonstruksi makna yang sudah mapan. Dalam tulisan ini, diuraikan strategi pembacaan secara dekonstruksi terhadap karakter Arjuna dengan menggunakan beberapa lakon wayang berbahasa Indonesia yang diterbitkan di majalah Cempala.

Mulawati mengkaji nilai karakter bangsa dalam nyanyian rakyat Muna di Provinsi Sulawesi Tenggara. Berdasarkan penelitian, unsur intrinsik nyanyian rakyat Muna menyiratkan nilai-nilai karakter bangsa seperti disiplin, selalu bekerja keras, mandiri, kreatif, dan toleransi.

Kami mengucapkan terima kasih kepada para penulis yang telah bersedia menerbitkan karya mereka pada edisi ini. Para penulis merupakan peneliti, pakar, dosen, guru, dan mahasiswa dari berbagai sekolah, perguruan tinggi, dan instansi. Terima kasih juga kami sampaikan kepada para mitra bestari yang telah memberi ulasan terhadap tulisan-tulisan yang masuk ke redaksi.

Demi memenuhi keberagaman isi dan penulis, Sirok Bastra membuka kesempatan bagi para peneliti dan penulis untuk menyampaikan hasil penelitian dan pemikiran mutakhir dalam bidang kebahasaan, kesastraan, dan pengajarannya.

Pangkalpinang, Desember 2014

\section{Tim Redaksi}




\section{UCAPAN TERIMA KASIH UNTUK MITRA BESTARI}

Redaksi Sirok Bastra mengucapkan terima kasih kepada para mitra bestari yang telah meninjau, menimbang, dan mengulas makalah-makalah yang diterbitkan dalam Sirok Bastra Volume 2 Nomor 2, edisi Desember 2014, yakni

\section{Prof. Dr. Agus Nuryatin, M.Hum.}

Bidang Sastra dan Pengajarannya

Universitas Negeri Semarang

Semarang, Jawa Tengah

Prof. Amrin Saragih, Ph.D., M.A.

Bidang Bahasa dan Pengajarannya

Universitas Negeri Medan

Medan, Sumatra Utara

\section{Dr. Felicia Nuradi Utorodewo, M.Hum.}

Bidang Bahasa dan Pengajarannya

Universitas Indonesia

Depok, Jawa Barat

\section{Dr. Pujiharto, M.Hum.}

Bidang Sastra dan Pengajarannya

Universitas Gadjah Mada

Yogyakarta, Daerah Istimewa Yogyakarta 


\section{DAFTAR ISI}

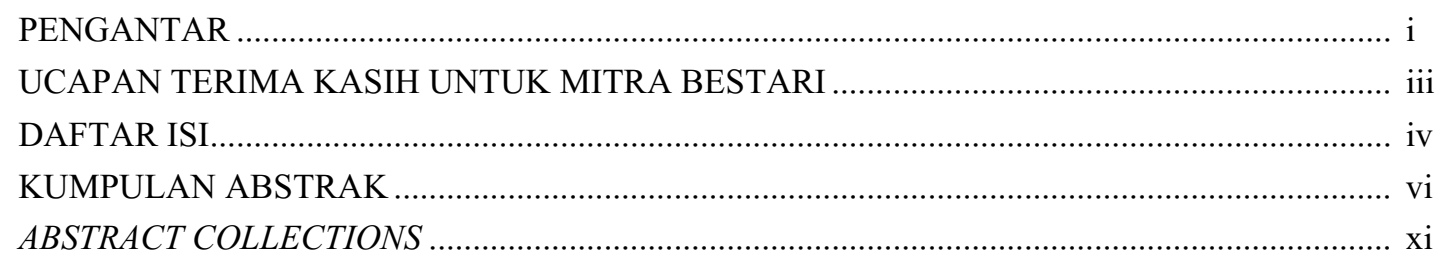

\section{UBRUG: KAJIAN SOSIOLINGUISTIK}

(Ubrug: Sociolinguistic Study)

Anitawati Bachtiar, Adek Dwi Oktaviantina, dan Rukmini $121-128$

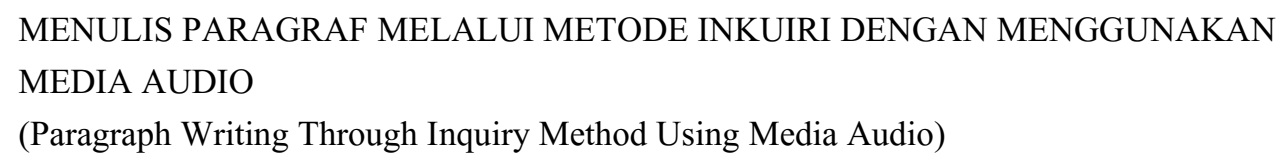

TEMA DAN AMANAT CERITA RAKYAT DI KECAMATAN KARANG INTAN, KABUPATEN BANJAR

(Theme and Message of Folklore in Karang Intan Subdistrict, Banjar Regency)

TATABUANG MANARE DAN BADENDANG DALAM PESTA PERNIKAHAN MASYARAKAT PULAU AMBON

(Tatabuang Manare and Badendang in Wedding Party of Ambon Island Society) 
MENGGUGAT ARJUNA SEBAGAI LELANANGING JAGAD: SEBUAH STRATEGI PEMBACAAN DEKONSTRUKSI KARAKTER ARJUNA DALAM LAKON-LAKON WAYANG PURWA

(Arjuna Sued as A Man of Universe: The Deconstruction of Reading Strategy for Arjuna's Character on Purwa Puppet Shows)

Bagus Kurniawan $193-200$

NILAI KARAKTER BANGSA DALAM NYANYIAN RAKYAT MUNA

(Nation Character Values in Munanese Folksong)

Mulawati $201-201$ 
Helmina Kastanya : Tatabuang Manare dan Badendang dalam Pesta Pernikahan ...

\title{
TATABUANG MANARE DAN BADENDANG DALAM PESTA PERNIKAHAN MASYARAKAT PULAU AMBON
}

\section{Tatabuang Manare and Badendang in Wedding Party of Ambon Island Society}

\author{
Helmina Kastanya \\ Kantor Bahasa Provinsi Maluku \\ Jalan Jenderal Soedirman, Batu Merah Atas, Ambon \\ Pos-el: emikastanya@yahoo.com
}

(diterima 18 September 2014, disetujui 6 November 2014, revisi terakhir 14 Desember 2014)

\begin{abstract}
Abstrak
Pulau Ambon merupakan wilayah ibu kota Provinsi Maluku yang memiliki segudang kekayaan sastra dan bahasa. Tradisi lisan tatabuang manare dan badendang merupakan salah satu kekayaan sastra yang mengandung nilai estetika dalam pesta pernikahan pada zaman dulu. Adapun permasalahan yang dikemukakan dalam penulisan ini adalah bagaimanakah bentuk, fungsi, dan nilai yang terkandung dalam tradisi lisan tatabuang manare dan badendang. Metode yang digunakan adalah metode kualitatif deskriptif. Hasil penelitian menunjukkan bahwa bentuk tradisi lisan tatabuang manare dan badendang adalah prosesi berbalas pantun sambil menari diringi alunan musik totobuang dan tifa. Tradisi ini berfungsi sebagai media penyatuan dua keluarga yang baru menjadi besan. Adapun nilai yang terkandung di dalamnya adalah nilai percintaan, kekeluargaan, dan sosial.
\end{abstract}

Kata kunci: tatabuang manare, badendang, pesta, pernikahan

\begin{abstract}
Ambon is a capital city of Maluku Province with enormous literature and language wealth. The oral tradition tatabuang manare and badendang are two of literature wealth containing aestethics value in wedding party since long time ago. The problems proposed in this writing are how is the form, function, and value containig in oral tradition tatabuang manare and badendang. The used method is descriptive qualitative method. The research result shows that the form of oral tradition tatabuang manare anf badendang are mutual response quatrain while dancing escorted with oscillation musical of tatabuang anf tifa. This tradition functions as unifying tool for two newly besan family. The values containing inside are love value, family, and social.
\end{abstract}

Keywords : tatabuang manare, badendang, wedding party

\section{PENDAHULUAN}

\subsection{Latar Belakang}

Kajian tentang tradisi lisan merupakan hal yang sangat penting karena dalam tradisi lisan terkandung banyak nilai positif yang dapat diterapkan dalam menjalani kehidupan bermasyarakat. Pada hakikatnya, tradisi lisan hadir di tengah-tengah masyarakat tradisional yang sangat menjaga dan memelihara Indonesia dari berbagai aspek kehidupan. Hal ini terkait dengan adanya pesan moral, kepercayaan, dan norma yang dipatuhi masyarakat demi keteraturan sistem sosial, serta nilai pendidikan yang dapat dijumpai di dalam tradisi lisan (Rahmana, 2012).
Perkembangan dan penyebaran tradisi lisan terjadi dari mulut ke mulut sehingga menimbulkan banyak versi cerita. Tradisi lisan tersebut mencakup beberapa hal, yakni (1) yang berupa kesusastraan lisan, (2) yang berupa teknologi tradisional, (3) yang berupa pengetahuan folklore di luar pusat-pusat istana dan kota metropolitan, (4) yang berupa unsur-unsur religi dan kepercayaan folklore di luar batas formal agamaagama besar, (5) yang berupa kesenian folklore di luar pusat-pusat istana dan kota metropolitan, dan (6) yang berupa hukum adat (Hutomo, 1991).

Hakikat kelisanan (orality), dalam hal ini tradisi lisan (oral tradition), mencakup segala hal yang berhubungan dengan sastera, bahasa, sejarah, biografi, 
dan berbagai pengetahuan serta jenis kesenian lain yang disampaikan dari mulut ke mulut. Jadi, tradisi lisan tidak hanya mencakup cerita rakyat, teka-teki, peribahasa, nyanyian rakyat, mitologi, dan legenda sebagaimana umumnya diduga orang, tetapi juga berkaitan dengan sistem kognitif kebudayaan, seperti sejarah, hukum, dan pengobatan. Tradisi lisan adalah segala wacana yang diucapkan/disampaikan secara turun-temurun, meliputi yang lisan dan yang beraksara dan diartikan juga sebagai sistem wacana yang bukan beraksara. Tradisi lisan tidak hanya dimiliki oleh orang lisan saja. Implikasi kata lisan dalam pasangan lisan-tertulis berbeda dengan lisanberaksara. Lisan yang pertama (oracy) mengandung maksud 'keberaksaraan bersuara', sedangkan lisan kedua (orality) mengandung maksud 'kebolehan bertutur secara beraksara'. Kelisanan dalam masyarakat beraksara sering diartikan sebagai hasil dari masyarakat yang tidak terpelajar; sesuatu yang belum dituliskan; sesuatu yang dianggap belum sempurna/matang, dan sering dinilai dengan kriteria keberaksaraan (Pudentia, 1998).

Dalam tradisi lisan, peranan orang yang dituakan seperti kepala suku atau ketua adat sangat penting. Mereka diberi kepercayaan oleh kelompoknya untuk memelihara dan menjaga tradisi yang diwariskan secara turun-temurun. Satu kelompok masyarakat dengan nilai, norma, tradisi, adat, dan budaya yang sama akan mempunyai jejak-jejak masa lampaunya. Dalam masyarakat yang belum mengenal tulisan, jejak-jejak masa lampaunya disebarluaskan dan diwariskan secara turun-temurun kepada generasi berikutnya secara lisan sehingga menjadi bagian dari tradisi lisan. Karya-karya dalam tradisi lisan merupakan bagian dari sebuah folklor. Tradisi lisan merupakan identitas komunitas dan salah satu sumber penting dalam pembentukan karakter bangsa melalui nilai-nilai luhur yang diwariskannya. Tradisi lisan juga dapat menjadi pintu masuk untuk memahami permasalahan masyarakat pemilik tradisi yang bersangkutan. Di dalam tradisi itu, kita dapat mengenal kehidupan komunitas suatu masyarakat mulai dari kearifan lokal, sistem nilai, pengetahuan tradisional, sejarah, hukum adat, pengobatan, sistem kepercayaan dan religi, astrologi, serta berbagai hasil seninya. Karena itu, tradisi lisan masih sangat relevan dengan kehidupan masyarakat sekarang (Pudentia, 1998).

Namun, pada kenyataannya, kita belum menghargai pentingnya tradisi lisan dalam kehidapan bermasyarakat. Tradisi lisan Nusantara, seperti dongeng, syair, puisi, pantun, dan teater, justru semakin berjarak dengan masyarakat, masih terpinggirkan, potensinya masih terabaikan, dan masih banyak yang menganggap bahwa tradisi lisan hanyalah peninggalan masa lalu yang hanya cukup menjadi kenangan manis belaka. Tradisi lisan seolaholah tidak relevan dengan kehidupan modern yang semakin maju saat ini. Dengan kata lain, pewarisan tradisi lisan ternyata tidak berjalan secara alamiah seperti yang diharapkan. Akibatnya, para penutur dan komunitas tradisi lisan di negeri ini semakin berkurang. Hal ini disebabkan ada berbagai kendala yang masih dihadapi dalam pengembangan dan penguatan tradisi lisan. Kendala tersebut antara lain belum siapnya kebijakan dalam strategi kebudayaan yang tepat, biaya terbatas, teknologi mengasingkan tradisi dari masyarakat, menurunnya peran masyarakat dan keluarga dalam menjaga warisan budaya. Hal seperti ini terjadi di berbagai daerah di Nusantara, termasuk di Pulau Ambon.

Pulau Ambon merupakan ibu kota Provinsi Maluku yang secara geografis memiliki wilayah pegunungan dan pesisir pantai. Kedua pembagian wilayah alamiah ini membentuk kebiasaan dan kehidupan masyarakat yang berbeda baik secara dialek maupun kebudayaan termasuk di dalamnya tradisi lisan.

Tatabuang manare dan badendang merupakan tradisi lisan yang memiliki fungsi dan nilai yang sama. Yang membedakan keduanya adalah bentuk atau pola ritme musiknya. Tatabuang manare merupakan istilah yang dipakai dalam masyarkat pegunungan, sedangkan badendang merupakan istilah yang dipakai oleh masyarakat yang hidup di daerah pesisir pantai. Tradisi lisan ini sudah hampir punah karena sudah sangat jarang dilakukan lagi. Faktor penyebabnya adalah anggapan bahwa tradisi lisan ini kuno dan ketinggalan zaman. Selain itu, gaya hidup masyarakat sudah berubah. Orang lebih cenderung memilih untuk melangsungkan pernikahan di gedung sehingga kebiasaan untuk melakukan pesta pernikahan di rumah sambil berpesta dengan iringan 
tifa dan totobuang tidak lagi digunakan sebagaimana fungsinya. Zaman sekarang, masih dijumpai penggunakan alat musik totobuang dan tifa, tetapi lebih umum difungsikan sebagai musik pengantar pengantin menuju tempat pernikahan atau untuk menyambut tamu. Penggunaannya tidak lagi berfungsi sebagai alat musik untuk menari dan berdendang sambil berbalas pantun untuk mengakrabkan dua keluarga yang baru menjadi besan karena pernikahan anak-anak mereka.

\subsection{Rumusan Masalah}

\subsubsection{Identifikasi Masalah}

Permasalahan dalam penelitian ini adalah tatabuang manare dan badendang dalam pesta pernikahan masyarakat Pulau Ambon merupakan sebuah tradisi lisan masyarakat yang sudah jarang dilaksanakan. Hal ini mengakibatkan berkurangnya rasa keakraban antara dua keluarga mempelai laki-laki dan perempuan.

\subsubsection{Pertanyaan Penelitian}

1. Bagaimanakah bentuk tradisi lisan tatabuang manare dan badendang dalam pesta pernikahan masyarakat di Pulau Ambon?

2. Bagaimanakah fungsi tatabuang manare dan badendang dalam pesta pernikahan masyarakat di Pulau Ambon?

3. Apa fungsi tatabuang manare dan badendang dalam pesta pernikahan masyarakat di Pulau Ambon?

\subsection{Tujuan}

Penelitian ini bertujuan untuk memerikan tradisi lisan tatabuang manare dan badendang dalam masyarakat Pulau Ambon. Untuk mencapai tujuan tersebut, dilakukan pemerian terhadap tiga aspek yaitu (1) bentuk tradisi lisan tatabuang manare dan badendang, (2) fungsi tradisi lisan tatabuang manare dan badendang, dan (3) nilai-nilai tradisi lisan tatabuang manare dan badendang. Secara representatif, ketiga aspek tersebut dianggap dapat mencerminkan tradisi lisan tatabuang manare dan badendang sebagai sebuah wacana budaya dan cerminan nilai-nilai budaya masyarakat Pulau Ambon.

\subsection{Manfaat}

Penelitian ini bermanfaat untuk mengingatkan kembali masyarakat Pulau Ambon akan pentingnya tatabuang manare dan badendang sebagai media penyatuan dan pengakraban dua keluarga laki-laki dan perempuan yang baru menikah.

\subsection{Metode}

Penelitian ini dilakukan di Pulau Ambon, yaitu di Kecamatan Nusaniwe dan Kecamatan Leitimur Selatan. Penelitian ini termasuk jenis penelitian kualitatif yang mengkaji bentuk, fungsi, dan nilai yang terkandung dalam tradisi lisan tatabuang manare dan badendang.

Data berupa tuturan lisan merupakan data utama yang menjadi fokus analisis. Pengumpulan data dilakukan melalui teknik pendokumentasian, wawancara, dan observasi. Dalam pengumpulan data, peneliti berfungsi sebagai instrumen kunci. Selain itu digunakan juga panduan observasi, panduan wawancara, alat perekam elektronik dalam pengambilan data. Aktivitas ini dilakukan untuk mendapatkan data tradisi lisan tabuang manare dan badendang yang berupa bentuk-bentuk tradisi lisan tatabuang manare dan badendang, fungsi tradisi lisan tatabuang manare dan badendang, serta nilai yang terkandung dalam tradisi lisan tatabuang manare dan badendang yang mengacu pada teori fungsi dalam penelitian folklor dan nilai-nilai tradisi lisan tatabuang manare dan badendang yang mencakup nilai sosial, nilai kekeluargaan, dan nilai etika masyarakat Pulau Ambon. Data yang didapatkan dideskripsikan secara kualitatif kemudian dilakukan interpretasi berdasarkan fakta-fakta yang diperoleh berdasarkan ide dan konsep yang terdapat dalam kebudayaan masyarakat setempat.

\section{KERANGKA TEORI}

Secara teori tradisi lisan banyak terdapat di masyarakat lokal. Aspek-aspek yang terkandung dalam tradisi lisan yaitu aspek sejarah, nilai-nilai moral, keagamaan, adat-istiadat, peribahasa, nyanyian, dan mantra. Menurut Boscon (dalam Nasha, 2013), tradisi lisan merupakan sistem proyeksi, yakni sebagai pencerminan angan-angan suatu masyarakat yang kolektif, sebagai alat pengesahan pranata-pranata dan lembaga-lembaga kebudayaan, sebagai alat pendidik anak, serta sebagai pemaksa atau pengawas agar norma-norma sosial dapat dipatuhi. Ciri-ciri tradisi lisan adalah pesan-pesan 
disampaikan secara lisan, yaitu melalui ucapan, nyanyian, maupun musik, dan tradisi lisan berasal dari generasi sebelumnya.

Menurut Kuntowijoyo (dalam Mulyadi, 2012), tradisi lisan merupakan salah satu sumber sejarah, sebab dalam tradisi lisan terekam masa lampau manusia yang belum mengenal tulisan entah terkait dengan kebiasaan, adat istiadat, kepercayaan, nilainilai, atau pengalaman sehari-hari mereka. Tradisi lisan terangkum dalam apa yang disebut folklor. Jejak sejarah masyarakat praaksara dalam bentuk dongeng, legenda, mitos, musik, upacara, pepatah, lelucon, takhayul, lagu rakyat, kebiasaan-kebiasaan, kepercayaan, alat musik rakyat, pakaian dan perhiasan tradisional, obat-obatan tradisional, arsitektur rakyat, dan kerajinan tangan merupakan bagian dari apa yang disebut folklor. Folklor adalah bagian dari kebudayaan suatu masyarakat yang tersebar dan bersifat tradisional yang diwariskan secara lisan dan turun-temurun. Setiap masyarakat atau kebudayaan di Nusantara memiliki folklornya sendiri, dan diwariskan dari generasi ke generasi.

Menurut Mulyadi (2012), folklor memiliki ciriciri: (1) penyebaran dan pewarisannya dilakukan secara lisan; (2) bersifat tradisional, artinya terkait dalam bentuk dan aturan yang baku; (3) bersifat anonim, artinya nama penciptanya tidak diketahui; (4) memiliki gaya bahasa yang suka melebih-lebihkan (hiperbola); (5) sering menggunakan kata-kata klise, misalnya jika ingin menggambarkan kecantikan seseorang akan dikatakan "wajahnya bersinar seperti bulan purnama", menggunakan kalimat pembuka dengan kata-kata, "menurut empunya cerita" atau "menurut sahibulhikayat", dan menutupnya dengan "demikianlah mereka hidup berbahagia selamanya"; (6) memiliki fungsi penting dalam kehidupan bersama dalam suatu masyarakat, selain sebagai hiburan dan pendidikan nilai, juga untuk menyampaikan proses sosial, bahkan untuk mengungkapkan keinginan yang terpendam; serta (7) merupakan milik bersama masyarakat pendukungnya.

\section{HASIL DAN PEMBAHASAN}

\subsection{Bentuk Tatabuang Manare dan Badendang}

Totobuang merupakan alat musik tradisional yang berasal dari daerah Maluku yang berbentuk deretan dua baris gong kecil yang berjumlah dua belas atau empat belas buah dan setiap gong kecil tersebut memiliki nada yang berbeda. Masyarakat Maluku menyebutkan gong kecil tersebut dengan istilah bonang. Totobuang dipakai sebagai sebuah musik pengiring dalam acara-acara tertentu dalam masyarakat. Walaupun totobuang dikenal sebagai salah satu alat musik tradisional daerah Maluku, tetapi alat musik tersebut bukan merupakan hasil ciptaan atau produksi orang Maluku. Hal ini disebabkan tradisi melebur logam bukan merupakan tradisi atau kebiasaan masyarakat di Maluku. Tradisi melebur logam hanya ada pada daerah yang bersentuhan langsung dengan kebudayaan dari India, seperti Sumatera, Jawa, Kalimantan, dan Bali.

Totobuang berasal dari gamelan Jawa yang berbentuk tetabuhan. Totobuang masuk di Ambon setelah runtuhnya kerajaan Majapahit, yaitu pada abad ke-16 Masehi. Invasi kebudayaan Jawa ke Nusantara termasuk di Maluku merupakan awal masuknya totobuang ke Maluku, yakni dibawa oleh para saudagar dari Pulau Jawa dan diberikan sebagai cenderamata, bukan sebagai alat musik. Kemudian totobuang dikembangkan oleh para leluhur sebagai sebuah bentuk akulturasi budaya. Bonang atau gong keil tersebut kemudian dimanfaatkan sebagai sebuah alat musik pengiring tarian atau lagu, terutama digunakan sebagai musik pengiring dalam acara pernikahan atau acara lain dalam masyarakat.

Dalam perkembangannya, masyarakat pada zaman dahulu bahkan sampai sekarang selalu memadukan totobuang dengan alat musik tifa. Pada zaman modern ini, totobuang dan tifa sudah dikembangkan lagi dengan memadukannya dengan alat musik modern sehingga dapat menghasilkan paduan musik yang sangat indah dan menarik. Namun, pada zaman dulu sebelum adanya perkembangan alat musik modern, masyarakat hanya menggunakan alat musik tifa dan totobuang sebagai musik pengiring dalam acara-acara perkawinan.

Tatabuang manare dan badendang merupakan kesenian yang berupa tradisi lisan yang hampir punah. Tradisi lisan ini berada di daerah pesisir dan daerah pegunungan. Tatabuang manare terdapat di daerah pesisir, yaitu di Kecamatan Nusaniwe, sedangkan badendang digunakan oleh masyarakat yang hidup di derah pegunungan, yaitu di Kecamatan Leitimur Selatan. Saat ini, pemainnya yang dapat dijumpai 
adalah musisi yang berusia $50-70$ tahun. Tradisi lisan ini diwariskan secara oral (oral tradition). Pada umumnya, musik tifa totobuang digunakan pada saat upacara adat dan mulai ditinggalkan oleh generasi muda karena dianggap kuno dan ketinggalan zaman.

Prosesi tatabuang manare dan badendang umumnya sama. Komponen pendukungnya adalah alat musik yang terdiri atas tifa dan totobuang, pemain alat musik, serta pelantun pantun. Dalam prosesinya, totobuang dibunyikan dengan tifa dan diikuti oleh lantunan syair-syair pantun yang diciptakan secara spontan dan langsung dinyanyikan. Antara pemantun yang satu dan yang lain saling berbalasan dengan melantunkan pantun yang berkesinambungan. Biasanya pantun dilantunkan sambil bergoyang dan menari, mengikuti irama musik tifa dan totobuang. Tarian tersebut bukanlah seperti tarian umumnya karena tidak memiliki pola dan umumnya dilakukan dengan menggerakan tangan ke atas sambil melambai-lambaikan sapu tangan berwarna putih.

Tatabuang manare dan badendang terdiri atas komposisi satu pemain alat musik totobuang, lima pemain tifa (terdiri dari pemain tifa jekir, tifa dasar, tifa potong, tifa jekir potong, dan tifa bas), serta pelantun pantun yang sekaligus berperan sebagai penari.

Prosesi tradisi ini dimulai dengan dipukulnya totobuang oleh pemain dan diikuti pemukulan tifa sesuai nada masing-masing. Kolaborasi bunyi tifa dan totobuang menghasilkan nada-nada yang indah dan khas. Mendengar irama musik totobuang dan tifa tersebut, para penari mulai bergoyang dan menari sambil melantunkan pantun yang secara spontan diciptakan. Setiap pantun yang disampaikan memiliki makna dan pesan bagi pendengar. Penyampaian pantun dilakukan secara berbalasan. Sebagai penanda atau kode bahwa sesorang akan menyampaikan pantun, diawali dengan menyampaikan "eeee..." (diikuti pantun yang ingin disampaikan). Setelah pantun disampaikan, semua pendukung atau pemain dan penonton yang ada sama-sama menyanyikan syair "manise e... manise e... su talalu manis e... sama santang dengan gula... su talalu manise e..." 'manis (indah)... manis (indah)... sangat manis (indah)... seperti santan dengan gula... sangat manis (indah)'. Setelah syair tersebut dinyanyikan secara bersama, pelantun pantun berikutnya secara spontan kembali menyampaikan kode "eeee...".

Pantun yang dinyanyikan dalam tatabuang manare dan badendang ialah pantun yang bertema percintaan, kasih sayang anak kepada orangtua, nasihat, keakraban, dan sebagainya. Pantun yang disampaikan selalu saling berkaitan satu dengan yang lain. Acara ini biasanya dilakukan apabila pesta pernikahan dilakukan di rumah dan waktu setelah resepsi pernikahan

\subsection{Fungsi Tatabuang Manare dan Badendang}

Badendang dan tatabuang manare merupakan tradisi masyarakat Maluku yang pernah tumbuh dan berkembang dalam masyarakat terutama pada acara pesta perkawinan. Fungsi totobuang itu sendiri menjadi penting dalam konteks tersebut. Tatabuang manare dan badendang pada zaman dulu dijadikan sebagai sarana untuk menyatukan dua keluarga mempelai perempuan dan keluarga mempelai laki-laki yang awalnya tidak saling mengenal menjadi lebih kenal, yang awalnya belum akrab menjadi lebih akrab. Suasana dua keluarga yang anak-anaknya baru saja menikah tentu belum terlalu intim, masih ada rasa sungkan dan tegang. Suasana ini diubah menjadi lebih akrab dengan melakukan aktivitas berbalas pantun dalam tatabuang manare dan badendang.

Selain berfungsi sebagai pengakraban dua keluarga mempelai perempuan dan laki-laki, tatabuang manare dan badendang biasanya menjadi sarana untuk menghibur orang. Kegiatan ini membuat orang lain ikut merasakan sukacita dan kebahagiaan yang dirasakan oleh keluarga yang punya acara tersebut.

\subsection{Nilai yang Terkandung dalam Tatabuang Manare dan Badendang}

Tatabuang manare dan badendang merupakan sebuah tradisi masyarakat Ambon yang dalam pengamatan saya memiliki kaitan antara permainan dengan pola kehidupan bermasyarakat. Permainan atau sajian tatabuang manare dan badendang dalam pesta perkawinan mengandung nilai yang sangat memengaruhi kehidupan masyarakat terutama pelakunya. Pesan yang ingin disampaikan dapat langsung didengar dan diterima oleh pendengar. Seperti halnya dengan tradisi lisan yang lain, nilai 
Helmina Kastanya : Tatabuang Manare dan Badendang dalam Pesta Pernikahan ...

yang terkandung dalam tradisi lisan tatabuang manare dan badendang memiliki pengaruh yang sangat besar bagi masyarakat.

Nilai-nilai yang terkandung dalam tradisi lisan tatabuang manare dan badendang antara lain (1) nilai percintaan, (2) nilai kekeluargaan, dan (4) nilai sosial. Keempat nilai ini sangat menonjol dalam tradisi tersebut. Hal ini dibuktikan melalui semua unsur pendukungnya. Berdasarkan fungsinya, sudah sangat jelas bahwa percintaan merupakan nilai yang paling menonjol dalam tradisi tatabuang manare dan badendang. Hal ini didukung dengan pantun yang diciptakan dan dilantunkan umumnya tentang ungkapan rasa cinta antara kedua mempelai, baik mempelai perempuan maupun mempelai pria.

\subsubsection{Nilai Percintaan}

Nilai percintaan dapat terlihat dalam kutipan pantun percintaan berikut ini yang digunakan dalam tradisi tatabuang manare dan badendang pada pesta pernikahan.

pagi hari su putar lagu landoke
dorang biking ribut di sabalah rumah
ale memang abuleke
romantis tarus deng tunangang lama
terjemahan
pagi hari sudah mainkan lagu Landoke (lagu khas
$\quad$ Minang)
tetangga rumah bikin gaduh
Anda memang tukang berbohong
romantis terus dengan pacar lama
baribu-ribu ular di sawa
cuma satu yang babisa
baribu-ribu nyong di dunia
cuma satu yang ade cinta
terjemahan
beribu-ribu ular di sawah
hanya satu yang berbisa
beribu-ribu lelaki di dunia
hanya satu yang ade (saya) cinta
makang mangga pake garam
mangga manis sama gula
biar ade kuli itang
tapi abang tagila-gila
terjemahan
makan mangga dicampur garam
mangga manis seperti gula

biar ade (saya) berkulit hitam

tapi abang tergila-gila

bua kadondong bua rambutang

cuci pring dibawa jambatang $e$

beta jodo ato bukang

yang penting katong dua pacarn e

terjemahan

buah kedondong, buah rambutan

cuci piring di bawah jembatan

saya jodoh atau bukan

yang penting kita berpacaran

\subsubsection{Nilai kekeluargaan}

Rasa kekeluargaan tidak selamanya ada pada orang-orang yang memiliki ikatan darah. Orang lain yang tidak sedarah dengan kita dapat menjadi bagian dari keluarga kita jika ada rasa sayang dan saling menerima. Berikut ini adalah contoh pantun yang mengandung nilai kekeluargaan yang dapat dipakai dalam tradisi lisan tatabuang manare dan badendang.

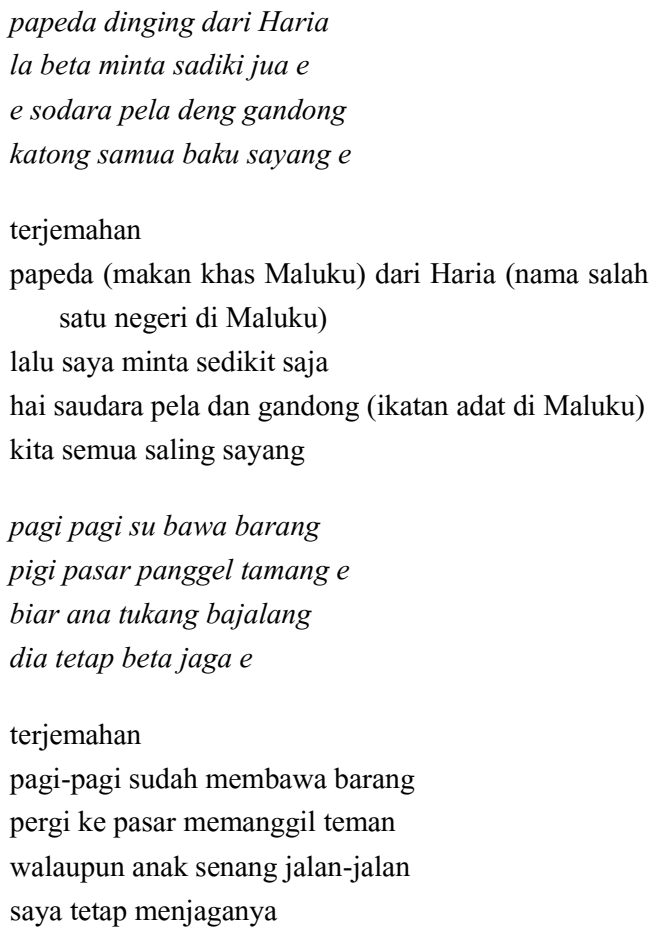

\subsubsection{Nilai Sosial}

Nilai sosial merupakan nilai yang dianut oleh suatu masyarakat mengenai apa yang dianggap baik dan yang dianggap buruk. Untuk mengetahui suatu hal itu baik atau buruk, harus dilakukan pertimbangan yang matang. Hal ini tentu dipengaruhi oleh budaya dan kepercayaan yang dianut suatu masyarakat. Berikut ini contoh pantun yang mengandung nilai 
sosial yang dapat digunakan dalam prosesi tatabuang manare dan badendang.

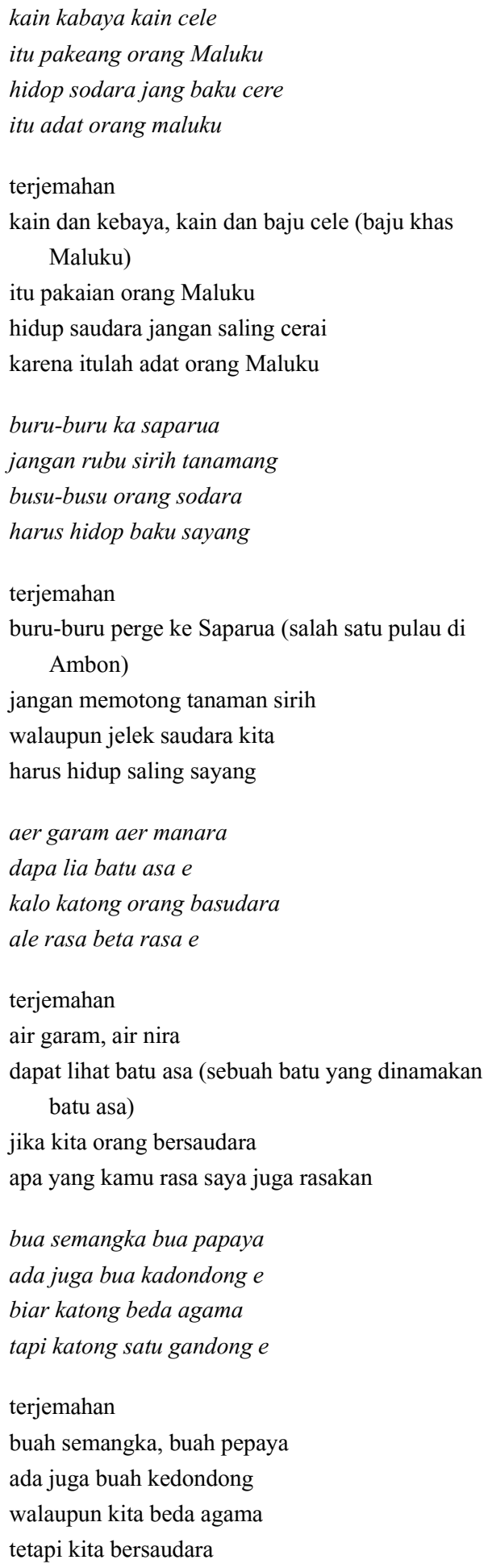

Selain nilai yang terkandung dalam syair-syair pantun, ketiga nilai tersebut dapat dilihat secara kompleks dari keseluruhan komponen pendukung. Memainkan alat musik totobuang dan tifa memerlukan kekompakan tim, keseriusan dan saling mendukung sehingga dapat menghasilkan perpaduan irama yang indah. Selain itu, para penari dan pelantun pantun harus mampu menyesuaikan diri, terutama dalam hal penyampaian pantun dibutuhkan saling kesinambungan, baik isi maupun maknanya. Hal ini menunjukkan bahwa ada nilai kecintaan dan nilai kebersamaan dalam tradisi lisan ini.

\section{PENUTUP}

\subsection{Simpulan}

Penulisan ini lebih ditekankan pada pemaparan bentuk, fungsi, dan nilai yang terkandung dalam tradisi lisan tatabuang manare dan badendang. Adapun bentuk dari tardisi lisan tatabuang manare dan badendang adalah tradisi berbalas pantun dan menari sambil diiringi oleh alat musik khas Maluku, yaitu tifa dan totobuang. Fungsi dari tardisi lisan tatabuang manare dan badendang adalah sebagai media penyatu dua keluarga yang baru menjadi besan. Tradisi ini dilakukan pada zaman dulu pada saat pesta pernikahan. Nilai yang terkandung dalam tardisi lisan tatabuang manare dan badendang adalah nilai percintaan, nilai kekeluargaan, dan nilai sosial. Nilainilai ini disimpulkan berdasarkan isi pantun yang disampaikan dan perpaduan komponen pendukung dan alat musik yang kompleks.

\subsection{Saran}

Kemajuan ilmu pengetahun, teknologi, dan informasi membuat zaman semakin berubah dan berkembang lebih modern. Seiring dengan hal tersebut, nilai-nilai kehidupan yang terkandung dalam tradisi dan kebudayaan masyarakat mulai tergilas. Oleh karena itu, hendaklah kita mampu mempertahankan tradisi dan kebudayaan kita yang telah diciptakan oleh para leluhur sebagai bentuk penghargaan untuk memperkokoh kehidupan masyarakat. Memegang teguh tradisi lisan masyarakat dapat berfungsi sebagai sarana untuk memahami dan mendalami nilai-nilai kehidupan sosial, keluarga, maupun pribadi dalam percintaan dan sebagainya. Tradisi lisan tatabuang manare dan badendang harus dilindungi dan direvitalisasi lagi karena memiliki fungsi dan peran yang sangat positif bagi masyarakat terutama dalam kehidupan bersama. 
Helmina Kastanya : Tatabuang Manare dan Badendang dalam Pesta Pernikahan ...

\section{DAFTAR PUSTAKA}

Endraswara, Suwardi. 2008. Metode Penelitian Sastra. Yogyakarta: FBS UNY.

Hutomo, Suripan Hadi. 1991. Mutiara yang Terlupakan: Pengantar Studi Sastra Lisan. Surabaya: HISKI Komisariat Jawa Timur.

Kardiani, Nasha, 2013. "Materi Antropologi XI Bahasa," dalam http://ivonsukma.wordpress.com/2012/10/10/materi-antropologi-xi-bahasa/, diakses 25 November 2014.

Moleong, Lexy. 2004. Metodologi Penelitian Kualitatif. Jakarta: Rosda.

Mulyadi, Tedy. 2012. "Perbedaan Tradisi, Tradisi Lisan, dan Folklor," dalam http://www.sridianti.com/perbedaan-tradisi-tradisi-lisan-dan-folklor.html, diakses 25 November 2014.

Pudentia M.P.S.S. 2008. Metodologi Kajian Tradisi Lisan. Jakarta: Asosiasi Tradisi Lisan.

Pudentia M.P.S.S. 1998. Metodologi Kajian Tradisi Lisan. Jakarta: Yayasan Obor Indonesia dan Yayasan Asosiasi Tradisi Lisan.

Rahmana, Siti. 2012. "Tradisi Lisan: Alkulturasi, Eksisitensi, dan Transformasi," dalam http://tempoinstitute.org/tradisi-lisan-aktualisasi-eksistensi-dan-transformasi-hasil-budaya-masa-lampau/, diakses pada tgl 24 November 2014.

Ratna, Nyoman Kutha. 2008. Teori, Teknik, dan Metode Penelitian Sastra. Yogyakarta: Pustaka Pelajar. Santosa, Puji. 1990. Ancangan Semiotika dan Pengkajian Susastra. Bandung: Angkasa. 